\title{
Kejadian Demam dan Kadlar IL-10 Serum Pasca Imunisasi DTwP/HepB Ketiga pada Bayi yang Mendapat dan Tiddak Mendapat ASI Eksklusif
}

\author{
Andri Firdaus, Alex Chairulfatah, Budi Setiabudiawan \\ Departemen Ilmu Kesehatan Anak Fakultas Kedokteran Universitas Padjadjaran/Rumah Sakit Dr. Hasan \\ Sadikin Bandung
}

Latar belakang. Dilaporkan bayi yang mendapat ASI eksklusif lebih jarang mengalami demam pasca imunisasi. Berbagai faktor yang berperan diantaranya adalah IL-10 yang banyak ditemukan dalam ASI.

Tujuan. Membandingkan kejadian demam dan kadar IL-10 serum pasca imunisasi DTwP/HepB ketiga antara bayi yang mendapat dan tidak mendapat ASI eksklusif.

Metode. Penelitian potong lintang dilaksanakan dari September-Desember 2012 melibatkan 70 bayi usia 4-6 bulan yang menerima imunisasi DTwP/HepB ketiga. Pengukuran suhu tubuh dilakukan sebelum, 30 menit, 6 jam, 12 jam, dan 24 jam pasca imunisasi atau saat demam dilakukan oleh ibu yang telah dilatih. Kadar IL-10 serum diperiksa dengan metode enzyme-linked immunosorbent assay (ELISA). Analisis statistik dilakukan dengan uji chi-kuadrat Pearson dan Mann-Whitney.

Hasil. Delapan dari 35 bayi yang mendapat ASI eksklusif (23\%) dan 32 dari 35 bayi yang tidak mendapat ASI eksklusif (91\%) mengalami demam pasca imunisasi $(\mathrm{p}<0,001$; RP 0,25). Demam pasca imunisasi timbul lebih cepat pada bayi yang tidak mendapat ASI eksklusif. Dari 24 bayi yang mengalami demam dalam 3 jam pasca imunisasi , 22 bayi (92\%) tidak mendapat ASI eksklusif dan 2 bayi (8\%) mendapat ASI eksklusif ( $\mathrm{p}<0,001)$. Rata-rata suhu pada bayi yang mendapat ASI eksklusif $37,8^{\circ} \mathrm{C}$, sedangkan yang tidak mendapat ASI eksklusif $38,1^{\circ} \mathrm{C}$ (p=0,033). Kadar IL-10 serum rata-rata bayi yang tidak mengalami demam pasca imunisasi 3,25 pg/mL, sedangkan yang mengalami demam 1,71 pg/mL (p<0,001). Kadar IL-10 serum rata-rata bayi yang mendapat ASI eksklusif 3,6 pg/mL, sedangkan yang tidak mendapat ASI eksklusif $1,1 \mathrm{pg} / \mathrm{mL}(\mathrm{p}<0,001)$.

Kesimpulan. Kemungkinan kejadian demam pasca imunisasi pada bayi yang tidak mendapat ASI eksklusif adalah 4 kali lebih tinggi dibandingkan bayi yang mendapat ASI eksklusif. Bayi yang tidak mendapat ASI eksklusif lebih cepat mengalami demam dengan suhu yang lebih tinggi. Bayi yang tidak mendapat ASI eksklusif mempunyai kadar IL-10 serum yang rendah daripada bayi yang mendapat ASI eksklusif. Sari Pediatri 2014;15(6):427-32.

Kata kunci: ASI eksklusif, demam, IL-10, imunisasi DTwP/HepB

Alamat korespondensi:

Prof. Alex Chairulfatah, dr. SpA(K). Departemen Ilmu Kesehatan Anak Fakultas Kedokteran Universitas Padjadjaran/Rumah Sakit Dr. Hasan Sadikin. Jl. Pasteur No. 38 Bandung 40163, Indonesia. Tel. 0222035957. Alamatemail:dianpus@bdg.centrin.net.id

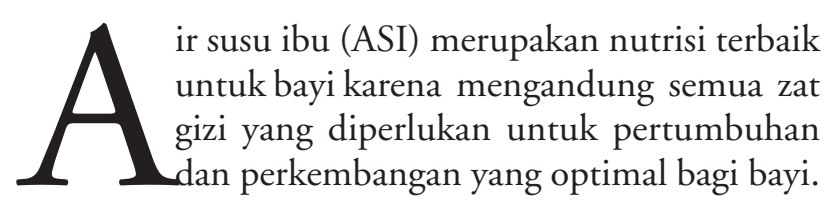


World Health Organization (WHO) merekomendasikan pemberian ASI eksklusif untuk bayi sejak lahir hingga usia 6 bulan dan dilanjutkan dengan pemberian ASI secara parsial (ASI disertai makanan tambahan) hingga usia 2 tahun. ${ }^{1,2}$ Air susu ibu mengandung berbagai zat antimikroba dan antiinflamasi serta memiliki aktivitas imunomodulator yang berperan dalam perkembangan respons imun pada bayi. ${ }^{3}$ Bayi yang memperoleh ASI akan memiliki respons imun yang berbeda terhadap beberapa vaksin jika dibandingkan bayi yang tidak memperoleh ASI. ${ }^{4-6}$ Imunisasi dapat menimbulkan berbagai efek samping mulai dari yang ringan sampai berat. ${ }^{7-11}$ Demam merupakan salah satu efek samping yang paling sering terjadi setelah imunisasi DTwP pada bayi ${ }^{4,11-13}$ sehingga sering menimbulkan kekhawatiran orang tua. ${ }^{14,15}$ Penelitian menunjukkan bahwa secara umum demam terjadi pada $1 \%-10 \%$ pasien vaksinasi dan kejadian ini meningkat hingga lebih dari 50\% setelah imunisasi DTwP., ${ }^{4,16,17}$ Frekuensi demam pasca imunisasi DTwP semakin meningkat pada imunisasi kedua, ketiga dan keempat, yaitu 39,6\% pada imunisasi DTP pertama menjadi $54,2 \%$ setelah imunisasi keempat. ${ }^{18-20}$

Terdapat sitokin antiinflamasi di dalam ASI, yaitu IL-10 dan TGF- $\beta 1$ serta antioksidan yang dapat menghambat proses inflamasi. ${ }^{21,22}$ Sedangkan IL-10 merupakan sitokin antiinflamasi dengan jumlah paling banyak ditemukan dalam $\mathrm{ASI}^{3}$ dan memiliki kemampuan menekan aktivitas sitokin proinflamasi dengan menghambat faktor-faktor transkripsi pada protein proinflamasi. ${ }^{21,23}$ Penelitian bertujuan untuk membandingkan kejadian demam pasca imunisasi DTwP/HepB yang ketiga dan kadar IL-10 antara bayi yang mendapat dan tidak mendapat ASI eksklusif.

\section{Metode}

Penelitian analitik observasional dengan rancangan potong lintang (cross sectional). Pengambilan data dilakukan secara purposif sampai jumlah subjek terpenuhi. Subjek penelitian adalah bayi yang mendapatkan imunisasi DTwP/HepB ketiga di Puskesmas Pasirkaliki, Sukajadi, dan Cipadung kota Bandung pada bulan September-Desember 2012. Kriteria inklusi adalah 1) bayi usia kurang dari 6 bulan yang secara klinis sehat, status gizi baik, 2) mendapatkan imunisasi DTwP/HepB yang ke-3. Kriteria eksklusi adalah 1) bayi yang diberikan obat penurun panas (antipiretik) sebelum dilakukan pengukuran suhu tubuh, 2) bayi yang mendapatkan imunisasi DTwP/ HepB di Puskesmas Pasirkaliki, Puskesmas Sukajadi, dan Puskesmas Cipadung tetapi bertempat tinggal di luar wilayah kerja Puskesmas tersebut. Pengukuran suhu tubuh dilakukan dari aksila oleh ibu yang telah mendapatkan pelatihan. Pengukuran suhu dilakukan sebelum imunisasi, 30 menit, 6 jam, 12 jam, dan 24 jam pasca imunisasi atau saat anak demam. Hasil pengukuran yang telah dicatat diambil oleh kader kesehatan dan diserahkan kepada peneliti.

Data demografis pengukuran suhu tubuh sebelum dan sesudah imunisasi, serta hasil pemeriksaan kadar IL-10 serum pasca imunisasi dicatat dalam formulir khusus. Pemeriksaan IL-10 serum menggunakan metode enzyme-linked immunosorbent assay (ELISA) dilakukan laboratorium Pusat Prodia Jakarta. Analisis data dilakukan dengan menggunakan program SPSS for windows versi 18.0 pada derajat kepercayaan 95\% dengan nilai $\mathrm{p} \leq 0,05$.

Protokol penelitian telah mendapat persetujuan Komite Etik Penelitian Kesehatan Fakultas Kedokteran Universitas Padjadjaran/RSUP Dr. Hasan Sadikin Bandung. Persetujuan ikut serta dalam penelitian didapatkan dari orangtua/wali subjek.

\section{Hasil}

Tujuh puluh bayi terdiri atas 37 (53\%) bayi lakilaki dan $33(47 \%)$ perempuan dengan rentang usia 4-6 bulan turut dalam penelitian. Tiga puluh lima bayi mendapatkan ASI eksklusif dan 35 bayi tidak mendapat ASI eksklusif, di antara kedua kelompok tidak terdapat perbedaan pada usia dan jenis kelamin (Tabel 1).

Tabel 1 Karakteristik subjek penelitian

\begin{tabular}{lcc}
\hline & \multicolumn{2}{c}{ Pemberian ASI (n=70) } \\
\cline { 2 - 3 } Karakteritik subjek & $\begin{array}{c}\text { ASI eksklusif } \\
(\mathrm{n}=35)\end{array}$ & $\begin{array}{c}\text { Non ASI eksklusif } \\
(\mathrm{n}=35)\end{array}$ \\
\hline Usia (bulan) & & \\
Rata-rata & 4,8 & 4,6 \\
Rentang & $(4-6)$ & $(4-6)$ \\
Jenis kelamin & & \\
Laki-laki & 17 & 20 \\
Perempuan & 18 & 15 \\
\hline
\end{tabular}


Kejadian demam, waktu mulai terjadi demam, dan suhu tubuh rata-rata saat demam pasca imunisasi $\mathrm{DTwP} / \mathrm{HepB}$ yang ketiga pada bayi yang mendapat ASI eksklusif dan tidak mendapat ASI eksklusif tertera pada Tabel 2.

Kejadian demam pasca imunisasi pada kelompok bayi yang mendapat ASI eksklusif adalah 8 dari 35 bayi (23\%), sedangkan pada kelompok bayi yang tidak mendapat ASI eksklusif adalah 32 dari 35 bayi (91\%) $(\mathrm{p}<0,001)$. Rasio prevalens (RP) 0,25 menunjukkan bahwa besarnya risiko untuk terjadinya demam pada bayi yang tidak mendapat ASI eksklusif sebanyak 4 kali lebih tinggi jika dibandingkan dengan bayi yang mendapat ASI eksklusif.
Pengukuran suhu tubuh sudah dijadwalkan pada 30 menit, 6 jam, 12 jam, dan 24 jam pasca imunisasi, tetapi sebagian orang tua melaporkan bahwa terjadi demam dalam 3 jam pasca imunisasi. Di antara 24 bayi yang mengalami demam dalam 3 jam pasca imunisasi, 22 bayi (92\%) tidak mendapat ASI eksklusif dan 2 bayi (8\%) mendapat ASI eksklusif ( $\mathrm{p}<0,001)$.

Suhu tubuh rata-rata saat demam pada bayi yang mendapat ASI eksklusif $37,8^{\circ} \mathrm{C}$, lebih rendah dari bayi yang tidak mendapat ASI eksklusif $38,1^{\circ} \mathrm{C}$ $(\mathrm{p}=0,033)$.

Pada seluruh subjek penelitian, kadar rata-rata IL-10 serum pada bayi yang tidak mengalami demam pasca imunisasi adalah $3,25 \mathrm{pg} / \mathrm{mL}$, lebih tinggi jika

Tabel 2. Kejadian demam, waktu terjadinya demam dan suhu tubuh saat demam pasca imunisasi DTwP/HepB yang ketiga

\begin{tabular}{|c|c|c|c|c|}
\hline \multirow{2}{*}{ Variabel demam } & \multicolumn{2}{|c|}{ Pemberian ASI } & \multirow[b]{2}{*}{$\mathrm{p}$} & \multirow{2}{*}{$\mathrm{RP}(95 \% \mathrm{CI})$} \\
\hline & $\mathrm{Ya}(\mathrm{n}=35)$ & Tidak $(n=35)$ & & \\
\hline \multicolumn{5}{|l|}{ Demam } \\
\hline Ada & 8 & 32 & \multirow[t]{2}{*}{$<0,001$} & 0,25 \\
\hline Tidak ada & 27 & 3 & & $(0,135-0,463)$ \\
\hline \multicolumn{5}{|c|}{ Waktu terjadinya demam pasca imunisasi (jam) } \\
\hline$\leq 3$ & 2 & 22 & \multirow[t]{2}{*}{$<0,001$} & \\
\hline$>3$ & 6 & 10 & & \\
\hline \multicolumn{5}{|c|}{ Suhu tubuh saat demam $\left({ }^{\circ} \mathrm{C}\right)$} \\
\hline Rerata (SB) & $37,8(0,41)$ & $38,1(0,40)$ & \multirow[t]{2}{*}{0,033} & \\
\hline Rentang & $37,5-38,5$ & $37,5-39,2$ & & \\
\hline
\end{tabular}

Keterangan: Nilai p untuk kejadian demam dan waktu terjadinya berdasarkan Uji Chi-kuadrat Pearson $\left(X^{2}\right)$

Nilai p untuk suhu tubuh saat demam berdasarkan Uji Mann-Whitney

Tabel 3. Hubungan kadar IL-10 dengan demam pasca imunisasi DTwP/HepB

\begin{tabular}{lcccc}
\hline \multirow{2}{*}{ Kadar IL-10 $(\mathrm{pg} / \mathrm{mL})$} & \multicolumn{2}{c}{ Pasca imunisasi } & $\mathrm{P}$ \\
\cline { 2 - 3 } & \multicolumn{2}{c}{$\mathrm{Z}_{\mathrm{M}-\mathrm{W}}$} & \\
\hline Seluruh Bayi & $1,71(1,59)$ & $3,25(1,64)$ & 5,122 & $<0,001$ \\
Rerata (SB) & $0,53-7,73$ & $0,96-6,82$ & & \\
Rentang & & & \\
\hline
\end{tabular}

Keterangan: Nilai p berdasarkan Uji Mann-Whitney $(Z)$

Tabel 4. Kadar IL-10 dengan ASI eksklusif

\begin{tabular}{lccc}
\hline \multirow{2}{*}{ Kadar I--10 $(\mathrm{pg} / \mathrm{mL})$} & \multicolumn{2}{c}{ Pemberian ASI } & \multirow{2}{*}{$\mathrm{p}$} \\
\cline { 2 - 3 } & ASI eksklusif $(\mathrm{n}=35)$ & Tidak ASI eksklusif $(\mathrm{n}=35)$ & \\
\hline Rerata (SB) & $3,6(1,75)$ & $1,1(0,36)$ & $<0,001$ \\
Rentang & $1,61-7,73$ & $0,53-2,03$ & \\
\hline
\end{tabular}

Keterangan: Nilai $p$ berdasarkan Uji t 
dibandingkan dengan bayi yang mengalami demam pasca imunisasi yaitu $1,71 \mathrm{pg} / \mathrm{mL}(\mathrm{p}<0,001)$ (Tabel 3).

Kadar rata-rata IL-10 serum pada bayi yang mendapat ASI eksklusif 3,6 pg/ml, lebih tinggi jika dibandingkan dengan bayi yang tidak mendapat ASI eksklusif $1,1 \mathrm{pg} / \mathrm{ml}(\mathrm{p}<0,001)$.

Kejadian ikutan pasca imunisasi selain demam, ditemukan 3 dari 70 bayi, berupa rewel pada satu orang bayi yang mendapat ASI eksklusif dan reaksi lokal berupa bengkak kemerahan pada lokasi penyuntikan pada 2 orang bayi yang tidak mendapat ASI eksklusif.

\section{Pembahasan}

Demam merupakan salah satu efek samping pasca imunisasi yang sering terjadi pada bayi..$^{411-13}$ Secara umum, demam terjadi pada $1 \%-10 \%$ bayi/anak yang divaksinasi dapat meningkat hingga lebih dari 50\% setelah imunisasi DTwP., ${ }^{4,13}$ Frekuensi demam pasca imunisasi DTwP meningkat setelah imunisasi yang pertama, 39,6\% pada imunisasi DTP yang pertama menjadi $54,2 \%$ setelah imunisasi yang keempat. ${ }^{18-20}$

Kejadian demam pasca imunisasi DTwP/HepB yang ketiga terjadi pada 57\% sedangkan 43\% tidak mengalami demam pasca imunisasi. Kejadian demam pasca imunisasi $\mathrm{DTw} / \mathrm{HepB}$ yang ketiga terjadi pada 32 bayi yang tidak mendapat ASI eksklusif, lebih banyak jika dibandingkan dengan bayi yang mendapat ASI eksklusif. Kemungkinan timbulnya demam pasca imunisasi DTwP/HepB ketiga pada bayi yang tidak mendapat ASI eksklusif adalah 4 kali lebih tinggi jika dibandingkan dengan bayi yang mendapat ASI ekskusif. Demam pasca imunisasi DTwP mulai terjadi dalam 12 jam pertama pasca imunisasi DTP, dan yang paling cepat terjadi pada 1 jam pasca imunisasi. ${ }^{19,20}$ Penelitian ini menunjukkan bahwa bayi yang tidak mendapat ASI eksklusif lebih cepat mengalami demam dibandingkan dengan bayi yang mendapat ASI eksklusif.

Demam merupakan respons sistemik peningkatan suhu tubuh yang diatur oleh pusat pengatur suhu pada area preoptik di hipotalamus. Mekanisme tersebut melibatkan sitokin proinflamasi yang bekerja sebagai pirogen endogen (IL-1, IL-6, TNF) dan sitokin-sitokin lain yang dapat berperan sebagai antiinflamasi (IL-10, IL-1 ra). ${ }^{24}$ Demam pasca imunisasi DTP dapat terjadi akibat inflamasi dan respons imun terhadap komponen vaksin. ${ }^{4,13,16}$ Demam yang terjadi pasca imunisasi DTP ini bervariasi dari hanya demam ringan sampai demam tinggi. ${ }^{8,19,20}$ Kejadian demam pasca imunisasi pada bayi yang mendapat ASI berhubungan dengan kandungan antiinflamasi dalam ASI yang dapat mengurangi kejadian demam karena produksi beberapa interleukin atau Toll-like receptor. ${ }^{4,24}$

Sitokin antiinflamasi yaitu IL-10 dan TGF- $\beta 1$ terdapat di dalam ASI serta antioksidan yang dapat menghambat proses inflamasi. ${ }^{21,22}$ Sitokin IL-10 merupakan sitokin antiinflamasi yang terbanyak ditemukan dalam ASI, ${ }^{3}$ diproduksi oleh sel $\mathrm{T}$ helper 2 (Th2), monosit, dan makrofag. Kemampuan IL10 menekan aktivitas sitokin proinflamasi dengan menghambat faktor-faktor transkripsi pada protein proinflamasi. ${ }^{23}$ Selain IL-10, ASI juga mengandung asam lemak tidak jenuh rantai panjang n-3 dan n-6 dengan jumlah yang lebih banyak dibandingkan susu formula. Asam lemak tersebut dapat mengurangi aktivitas mediator inflamasi IL-1 dan TNF yang berperan dalam patogenesis demam. ${ }^{6,22,25-27}$

Kadar IL-10 serum rata-rata pada bayi yang tidak mengalami demam $3,25 \mathrm{pg} / \mathrm{mL}$, lebih tinggi jika dibandingkan dengan bayi yang mengalami demam pasca imunisasi $1,71 \mathrm{pg} / \mathrm{mL}$. Hal tersebut menunjukkan bahwa kadar IL-10 yang tinggi dalam darah bayi kemungkinan berhubungan dengan kejadian demam yang rendah pasca imunisasi. Hasil penelitian ini diperkuat dengan kadar IL-10 serum rata-rata pada bayi yang mendapat ASI eksklusif 3,6 $\mathrm{pg} / \mathrm{mL}$, lebih tinggi dari bayi yang tidak mendapat ASI eksklusif yaitu $1,1 \mathrm{pg} / \mathrm{mL}$.

Selain demam, imunisasi DTP dapat menyebabkan kejadian ikutan pasca imunisasi, seperti reaksi lokal kemerahan, bengkak, dan nyeri pada lokasi injeksi yang terjadi pada separuh $(42,9 \%)$ penerima DTP. Reaksi sistemik seperti anak gelisah dan menangis terus selama beberapa jam pasca suntikan (inconsolable crying), kejang demam yang berhubungan dengan demam yang terjadi pasca imunisasi, ensefalopati atau reaksi anafilaksis. ${ }^{28}$ Namun, kejadian ikutan pasca imunisasi $\mathrm{DTw} / \mathrm{HepB}$ yang ketiga selain demam pada penelitian ini hanya ditemukan sedikit reaksi lokal pada bayi yang tidak mendapat ASI.

Pada penelitian ini pengambilan sampel subjek penelitian dilakukan secara purposif. Agar hasil penelitian dapat diterapkan pada populasi yang lebih luas, diperlukan penelitian dengan subjek yang lebih besar dan metode pengambilan sampel secara acak. 


\section{Kesimpulan}

Kejadian demam pasca imunisasi pada bayi yang tidak mendapat ASI eksklusif empat kali lebih tinggi dibandingkan bayi yang mendapat ASI eksklusif. Bayi yang tidak mendapat ASI eksklusif lebih cepat mengalami demam dan lebih tinggi dibandingkan dengan bayi yang mendapat ASI eksklusif. Bayi yang tidak mendapat ASI eksklusif memiliki kadar IL-10 yang rendah kemungkinan berhubungan dengan kejadian demam pasca imunisasi.

\section{Daftar pustaka}

1. World Health Organization. Global strategy for infant and young child feeding. 2003 [diunduh 25 Desember 2010]. Didapat dari:: http://whqlibdoc.who.int/ publications/2003/9241562218.pdf.

2. Gartner L, Morton J, Lawrence R. Breastfeeding and the use of human milk. Pediatrics 2005;115:496-506.

3. Garofalo R. Cytokines in human milk. J Pediatr 2010;156:36-40.

4. Pisacane A, Continisio P, Palma O, Cataldo S, Michele F, Vairo U. Breastfeeding and risk for fever after immunization. Pediatrics 2010;125:1448-52.

5. Silfverdal S, Ekholma L, Bodin L. Breastfeeding enhances the antibody response to Hib and Pneumococcal serotype $6 \mathrm{~B}$ and 14 after vaccination with conjugate vaccines. Vaccine 2007;25:1497-502.

6. Fadlyana E, Tanuwidjaja S, Rusmil K, Dhamayanti M, Soemara L, Dharmayanti R. Imunogenitas dan keamanan vaksin DPT setelah imunisasi dasar. Sari Pediatri 2002;4:129-34.

7. Jong D, Tumbelaka A, Latief A. Adverse events following immunization of combined diphteria, whole-cell pertussis, tetanus, and hepatitis B (DPwT/HB) vaccine. Paediatr Indones 2004;44:209-14.

8. Wahab A, Julia M. Sistem imun, imunisasi, dan penyakit imun. Jakarta: Widya Medika; 2002.

9. Knufa M, Habermehl P, Cimino C, Petersen G, Schmitt J. Immunogenicity, reactogenicity and safety of a 7-valent pneumococcal conjugate vaccine (PCV7) concurrently administered with a DTPa-HBV-IPV/Hib combination vaccine in healthy infants. Vaccine 2006;24:4727-36.

10. Pichichero M, Bernstein H, Blatter M, Schuerman L, Cheuvart B, Holmes S. Immunogenicity and safety of a combination diphtheria, tetanus toxoid, acellular pertussis, hepatitis $B$, and inactivated poliovirus vaccine coadministered with a 7-valent pneumococcal conjugate vaccine and a haemophilus influenzae type b conjugate vaccine. J Pediatr 2007;151:43-9.

11. Avner J. Acute fever. Pediatr Rev 2009;30:5-13.

12. Kohl K, Marcy S, Blum M, Jones M, Dagan R, Hansen J, dkk. Fever after immunization: Current concepts and improved future scientific understanding. Vaccine. 2004;39:389-94.

13. Marcy S, Kohl K, Dagan R, Nalin D, Blum M, Jones M, dkk. Fever as an adverse event following immunization: case definition and guidelines of data collection, analysis, and presentation. Vaccine 2004;22:551-6.

14. Lawrence R, Pane C. Human breast milk: current concepts of immunology and infectious disease. Curr Probl Pediatr Adolesc Health Care 2007;37:7-36.

15. Asadullah K, Sterry W, Volk H. Interleukin-10 therapy: review of a new approach. Pharmacol Rev 2003;55:24169.

16. Cody C, Barraf L, DCherry J, Marcy M, Manclark C. Nature and rates of adverse reactions associated with DTP and DT immunizations in infants and children. Pediatrics 1981;68:650-60.

17. Jaber L, Ashkenazi S. Characterization of the febrile response to diphteria-tetanus-pertussis vaccination. International Journal of Risk \& Safety in Medicine 2000;13:23-7.

18. Freitas F, Sato H, Aranda C, Arantes B, Pacheco M, Waldman E. Adverse events following diphteria, pertussis and tetanus vaccinations and factors associated with severity. Rev Saude Publica 2007;41:1-10.

19. Verschoor P, Wilschut J, Jonge G. Frequent symptoms after DTPP vaccinations. Arch Dis Child 1991;66:1408-12.

20. Conti B, Tabarean I, Andrei C, Bartfai T. Cytokines and Fever. Frontiers in Bioscience 2004;9:1433-49.

21. Mann D. Breastfeeding cuts fever risk after vaccines. 2010 [diunduh 8 November 2010]. Didapat dari: http:// www.webmd.com.

22. Granot E, Golan D, Berry E. Breast-fed and formula-fed infants do not differ in immunocompetent cell cytokine production despite differences in cell membrane fatty acid composition. Am J Clin Nutr 2000;72:1202-5.

23. Alarcon M, Garza C, Habicht J, Martınez L, Pegueros $\mathrm{V}$, Villalpando S. Breastfeeding attenuates reductions in energy intake induced by a mild immunologic stimulus represented by DPTh immunization: possible roles of interleukin-1, tumor necrosis factor and leptin. J Nutr 2002;132:1293-98.

24. Tumbelaka A, Hadinegoro S, Ismoedijanto. Difteria, tetanus, pertusis. Dalam: Ranuh I, Suyitno H, 
Andri Firdaus dkk: Kejadian demam dan kadar IL-10 serum pasca imunisasi DTwP/HepB ketiga

Hadinegoro S, Kartasasmita C, Ismoedijanto, Soedjatmiko, penyunting. Pedoman imunisasi di
Indonesia. Edisi ke-4. Jakarta: Badan Penerbit IDAI; 2008.h.289-302. 